\title{
REVISTAMARACANAN
}

Artigo

\section{A organização dos comunistas na região Sul Fluminense no período pré-golpe civil-militar (Barra Mansa, Volta Redonda, Barra do Piraí e Piraí)}

\author{
The organization of the communists in the Southern region of Rio de Janeiro \\ in the pre-civil-military coup (Barra Mansa, Volta Redonda, Barra do Piraí and \\ Piraí)
}

André Rocha Carneiro*

Universidade do Estado do Rio de Janeiro, Brasil

Lúcia Maria de Assis**

Universidade Federal Fluminense, Brasil

Recebido: 13 abr. 2017.

Aprovado: 09 set. 2018.

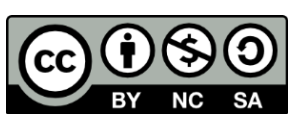

Este artigo foi produzido no âmbito do projeto de pesquisa "O $1^{\circ}$ Batalhão de Infantaria Blindada do Exército e a repressão militar no Sul Fluminense", financiado pela FAPERJ e desenvolvido na Universidade Federal Fluminense.

* Doutorando em História pela Universidade do Estado do Rio de Janeiro (UERJ). Mestre em História pela UERJ; Especialista em História do Brasil pela Universidade Federal Fluminense; e, Licenciado em História por esta mesma instituição. (andrerochacarneiro780@gmail.com)

CV Lattes: http://lattes.cnpq.br/2050894878293263.

** Professora Associada na Universidade Federal Fluminense. Doutora em Linguística pela Universidade de São Paulo e Mestre em Linguística Aplicada ao Ensino da Língua Materna pela Universidade de Taubaté. Integra o grupo de pesquisadores do Centro de Memória do Sul Fluminense - CEMESF. (lucia.a@uol.com.br)

CV Lattes: http://lattes.cnpq.br/8169985059176655. 


\section{Resumo}

Neste artigo trataremos da organização dos comunistas na região do Vale do Paraíba fluminense, mais especificamente nos municípios de Barra Mansa, Volta Redonda, Barra do Piraí e Piraí, no período que antecede o golpe civil-militar de 1964. Esta região se encontrava com grande concentração de operários devido à presença, entre outras indústrias, da CSN (Companhia Siderúrgica Nacional), a maior siderúrgica da América Latina, base da política do desenvolvimentismo nacional do governo Getúlio Vargas. Devido a essa concentração de trabalhadores, os comunistas procuraram se estabelecer a fim de criar bases partidárias. Também por esse motivo foi instalado, em Barra Mansa, o Primeiro Batalhão de Infantaria Blindada (10 BIB), com o objetivo de proteger as instalações industriais da região. A presença do $1^{0}$ BIB na vida cotidiana dos habitantes desses municípios foi fator fundamental para apoiar o golpe civil-militar e reprimir os seus opositores, entre eles os comunistas.

Palavras-chave: Golpe Civil-Militar. Vale do Paraíba. Comunistas.

\section{Abstract}

In this article we will discuss the organization of the communists in the Paraíba region of Rio de Janeiro, specifically in the municipalities of Barra Mansa, Volta Redonda, Barra do Piraí and Piraí before the 1964 civil-military coup. A large concentration of workers due, among other industries, to the presence of CSN (Companhia Siderúrgica Nacional), the largest steelmaker in Latin America, the basis of the national development policy of the Getúlio Vargas government. Because of this concentration of workers, the PCB sought to establish itself in order to create party bases. Also for this reason, the First Armored Infantry Battalion (1st BIB) was installed in Barra Mansa, in order to protect the industrial facilities of the region. The presence of the 1st BIB in the daily life of the inhabitants of these municipalities was a fundamental factor in supporting the civil-military coup and repressing its opponents, among them the communists.

Keywords: Civil-Military Coup. Paraíba Valley. Communists. 


\section{Introdução}

A região do vale do Paraíba fluminense, especialmente os municípios de Barra Mansa, Volta Redonda, Barra do Piraí e Piraí, desde os anos 1940, possuía grande concentração de indústrias, entre as quais se sobressaía a Companhia Siderúrgica Nacional (CSN), a maior siderúrgica da América Latina. Devido à importância da CSN para o desenvolvimento do país e à grande concentração de trabalhadores, na década de 1950 essa região recebeu uma importante unidade militar, o $1^{\circ}$ Batalhão de Infantaria Blindada (10 BIB), com sede em Barra Mansa, o qual tinha por objetivo o controle militar da população regional.

Cumprindo o papel de controlador e mantenedor da ordem, em abril de 1964, logo após o golpe civil-militar, o $1^{0}$ BIB instaurou um Inquérito Policial Militar (IPM) contra grupos políticos que agiam na região. Tratava-se, de uma ação do Exército brasileiro para combater aqueles que haviam apoiado o governo de João Goulart, apeado do poder por uma coalizão de forças civis e militares. A abertura do referido IPM documenta a existência de um grupo comunista articulado na região, o que poderia significar riscos à ordem objetivada pelo governo ditatorial. Diante disso, surge a pergunta que norteia este trabalho: Como se organizava o grupo comunista com base no sul fluminense? Pretendemos, portanto, a partir da análise desse processo - o IPM -, descrever como os comunistas se organizavam e quais atividades desenvolviam na região sul fluminense, no período que antecede o golpe civil-militar de 1964.

Para responder à questão norteadora, este trabalho seguirá as seguintes etapas:

- Primeiramente, faremos uma contextualização do período denominado pré-golpe, que se refere especificamente aos anos que, mais de perto, antecederam o período ditatorial. Para tal descreveremos o que ocorria entre os anos 1960 e 1964;

- Em seguida, analisaremos, de forma mais detida, como o Partido Comunista se relaciona com a organização dos trabalhadores no Brasil, inclusive procurando demonstrar certa confusão que existia entre as denominações PCB e PC do B. Essa análise exige que se retorne aos anos 1940;

- Num terceiro momento, abordaremos a ação de Brizola na tentativa de criação dos "Grupos de Onze", pequenos grupos compostos por 11 pessoas que teriam como objetivo organizar a população para que pudesse defender a si e seus interesses contra aqueles que pretendiam ceifar a democracia e as conquistas dela advindas. Há registros de que células de Grupos de Onze foram organizadas no Sul Fluminense;

- Em seguida, abordaremos a criação do 10 BIB em Barra Mansa, que ocorreu no ano de 1950, com a intenção de proteger a CSN, indústria que, naquele momento, era imprescindível para o desenvolvimento do Brasil; 
Finalmente chegaremos ao Inquérito Policial Militar que anuncia existência, prisão e condenação de pessoas ligadas ao comunismo na região, sob a alegação de que "conspiravam" contra o governo e ofereciam grande risco à ordem pública e ao país. É a partir desse inquérito que conseguiremos nomear as pessoas que compunham o partido comunista no Sul fluminense.

\section{O Período Pré-golpe}

O governo de Jango, como era conhecido o então presidente da República João Goulart, havia alçado ao poder com a renúncia do presidente Jânio Quadros, em 1961. Jango fora eleito vice-presidente na chapa do general Henrique Teixeira Lott, que perdera as eleições para Jânio Quadros. ${ }^{1}$ Jango era do Partido Trabalhista Brasileiro (PTB), partido criado por Getúlio Vargas, ligado aos movimentos sindicais criados na chamada Era Vargas, primeiro período em que Vargas governou o país. Nesse período, Vargas implantou diversos direitos trabalhistas, organizando os sindicatos de forma a terem uma ligação mais orgânica e harmônica com o governo, principalmente com a adoção do imposto sindical, que formava um fundo financeiro a ser liberado apenas para os sindicatos que se alinhavam com o governo.

Por conta de sua formação trabalhista, Jango não era bem visto pelas forças conservadoras, principalmente aquelas encasteladas entre o alto oficialato das Forças Armadas que, em meio a um período de Guerra Fria, consideravam-no comunista ou ligado a grupos comunistas que teriam por objetivo implantar esse regime no Brasil. Os grupos de oposição, encabeçados pelos militares, não admitiam que Jango assumisse a presidência da República após a renúncia de Jânio Quadros.

Entretanto, devido à forte resistência das forças políticas que apoiavam Jango, lideradas por Leonel Brizola, governador do Rio Grande do Sul, na chamada Campanha da Legalidade, e também ao apoio recebido do $3^{\circ}$ Exército, comandado pelo general José Machado Lopes, Jango assumiu a presidência. Apesar disso, teve de negociar com as forças opositoras e admitir a adoção do sistema parlamentarista, ${ }^{2}$ ainda em 1961, perdendo a parte de seus poderes concernentes ao governo propriamente dito. Nessa época, seu governo já enfrentava problemas com a inflação, o endividamento externo, o déficit no balanço de pagamentos e a recessão econômica.

\footnotetext{
${ }^{1}$ Naquela época a lei eleitoral permitia que as candidaturas da chapa presidencial pudessem ser votadas separadamente. NICOLAU, Jairo. Eleições no Brasil: do Império aos dias atuais. Rio de Janeiro: Zahar, 2012 , p.122.

${ }^{2}$ Segundo a Emenda Constitucional n. ${ }^{\circ} 4$, de 2 de setembro de 1961, o Poder Executivo passava a ser exercido pelo Presidente da República e pelo Conselho de Ministros, cabendo a este a direção e a responsabilidade da política do Governo, assim como da administração federal. Caberia ao Presidente da República nomear o Presidente do Conselho de Ministros e, por indicação deste, os demais Ministros de Estado, exonerando-os quando a Câmara dos Deputados lhes retirasse a confiança.
} 
Mais tarde, com seus poderes restabelecidos devido ao plebiscito de 6 de janeiro de 1963, ${ }^{3}$ Jango tentou emplacar o Plano Trienal de desenvolvimento econômico-social (19631965) elaborado por Celso Furtado, que pretendia, inicialmente, conter o aumento da massa salarial para combater a inflação, o que desagradava os setores sindicais. A retirada dos subsídios para o trigo e o petróleo e o corte de investimentos públicos levaram as representações do Comando Geral dos Trabalhadores (CGT) ${ }^{4}$, do Pacto de Unidade e Ação (PUA) ${ }^{5}$ da Frente Parlamentar Nacionalista (FPN), ${ }^{6}$ da União Nacional dos Estudantes (UNE) ${ }^{7}$ e dos nacionalistas do PTB a se unirem na condenação ao Plano do governo ${ }^{8}$.

O fracasso do Plano levou o governo Jango a defender a necessidade de reformas sociais, que passaram a ser vistas pelos setores ligados à esquerda do espectro político - entre eles a Frente de Mobilização Popular (FMP), ${ }^{9}$ a UNE, o CGT, a PUA e a FPN - como necessárias

\begin{abstract}
${ }^{3} \mathrm{Em}$ junho de 1962, o gabinete de Tancredo se dissolveu sob o argumento de que seus membros precisavam se desincompatibilizar para as eleições de outubro. Jango, pretendendo reconquistar os poderes presidenciais, se aproximou dos movimentos operários e nacionalistas. A indicação de San Tiago Dantas fora derrotada, saindo vitorioso Auro de Moura Andrade, do PSD, para primeiro-ministro. Em face de uma forte greve, o Congresso destituiu Andrade e aprovou a indicação de Brochado da Rocha, trabalhista do Rio Grande do Sul. A emenda constitucional previa para 1965 um plebiscito sobre a volta do presidencialismo, mas a crise política e a ameaça de uma nova greve fizeram com que o Congresso o antecipasse para 6 de janeiro de 1963. Jango negociou com forças conservadoras a volta do presidencialismo. Além dele, outros desejavam a derrota do parlamentarismo com vistas às eleições presidenciais de 1965, como Magalhães Pinto, Carlos Lacerda, Juscelino Kubitschek e Ademar de Barros. A derrota do parlamentarismo fora resultado de forças antagônicas que queriam desde as reformas de base até a repressão dos trabalhadores. GORENDER, Jacob. Combate nas Trevas. A esquerda brasileira: das ilusões perdidas à luta armada. São Paulo: Ática, 1987.

${ }^{4}$ Organização intersindical de trabalhadores, de âmbito nacional, não reconhecida pelo Ministério do

Trabalho, criada durante o IV Congresso Sindical Nacional dos Trabalhadores, realizado em São Paulo em agosto de 1962, com o objetivo de orientar, coordenar e dirigir o movimento sindical brasileiro. Cf.: Comando Geral dos Trabalhadores (CGT). (Verbete). Disponível em: http://www.fgv.br/cpdoc/acervo/dicionarios/verbete-tematico/comando-geral-dos-trabalhadores-cgt. Acesso em: 20 jun. 2017.

${ }^{5}$ Organização intersindical de trabalhadores ferroviários, marítimos e portuários não reconhecida pelo Ministério do Trabalho, constituída formalmente no Rio de Janeiro, então estado da Guanabara, em maio de 1961. Cf.: Pacto de Unidade e Ação (PUA). (Verbete). Disponível em:
\end{abstract} http://www.fgv.br/cpdoc/acervo/dicionarios/verbete-tematico/pacto-de-unidade-e-acao-pua. Acesso em: 20 jun. 2017.

${ }^{6}$ Grupo que, nas legislaturas entre 1956 e 1964, reuniu deputados de vários partidos políticos comprometidos em defender, no Congresso Nacional, políticas e soluções nacionalistas para os problemas do desenvolvimento brasileiro. Cf.: Frente Parlamentar Nacionalista (FPN). (Verbete). Disponível em: http://www.fgv.br/cpdoc/acervo/dicionarios/verbete-tematico/frente-parlamentar-nacionalista-fpn. Acesso em: 20 jun. 2017.

${ }^{7}$ Organização fundada extraoficialmente em 11 de agosto de 1937 por iniciativa da Casa do Estudante do Brasil, no Rio de Janeiro, então Distrito Federal, por ocasião do I Conselho Nacional de Estudantes e, reconhecida oficialmente no ano seguinte. A UNE era constituída pelas organizações estudantis brasileiras a ela filiadas, sendo "o órgão máximo de representação dos estudantes" e tendo por finalidade "congregar todos os estudantes do Brasil para a defesa dos seus interesses". Cf.: União Nacional dos Estudantes (UNE). (Verbete). Disponível em: http://www.fgv.br/cpdoc/acervo/dicionarios/verbetetematico/uniao-nacional-dos-estudantes-une. Acesso em: 20 jun. 2017.

8 TOLEDO, Caio Navarro de. 1964: O golpe contra as reformas e a democracia. Revista Brasileira de História, São Paulo, v. 24, n. 47, 13-28, 2004.

${ }^{9}$ Movimento nacionalista surgido em 1962 com o objetivo de pressionar em favor da implementação das chamadas reformas de base (agrária, urbana, tributária, bancária e constitucional). Liderado pelo governador do Rio Grande do Sul, Leonel Brizola, congregou representantes de organizações como o Comando Geral dos Trabalhadores (CGT), o Pacto de Unidade e Ação (PUA), a União Nacional dos Estudantes (UNE) e a União Brasileira dos Estudantes Secundários (UBES), além de elementos da Frente Parlamentar Nacionalista (FPN) e de entidades camponesas e femininas como a Frente Nacionalista Feminina. Cf.: Frente de Mobilização Popular (FMP). (Verbete). Disponível em: 
para se atingir o desenvolvimento econômico e social e ampliar a democratização do país. ${ }^{10}$ Para estes, as chamadas Reformas de Base, distribuiriam melhor a riqueza nacional e também combateriam as desigualdades sociais e regionais. As Reformas de Base eram um conjunto de reformas em diversos setores sociais, políticos e econômicos. Entre elas constavam a reforma agrária, a reforma urbana, a administrativa, a bancária e a universitária, além da extensão do voto aos analfabetos e subalternos das Forças Armadas. Esse conjunto de reformas, elaborado por setores progressistas desde a década de 1950, pretendia dinamizar o capitalismo no país por um viés de maior participação popular e com maior distribuição de riquezas.

Jango precisava do apoio do Congresso para aprovar as reformas, porém encontrava resistência de setores mais conservadores, como os latifundiários, as grandes corporações empresariais com forte participação do capital internacional, principalmente norte-americano, ${ }^{11}$ e parte da classe média. Esses setores mais conservadores, em época de Guerra Fria, viam as reformas como uma tentativa indireta de instalar o comunismo no Brasil. Nas negociações com os congressistas, Jango tentava se aproximar do Partido Social Democrático (PSD) e da parcela mais progressista da União Democrática Nacional (UDN), maior partido de oposição ao seu governo. ${ }^{12}$ Essa tentativa conciliatória era, porém, condenada por setores mais à esquerda do espectro político, como o grupo liderado por Brizola e o Partido Comunista Brasileiro $(\mathrm{PCB})$. $^{13}$

O PCB, desde a Declaração de Março de 1958, havia deixado sua postura mais favorável a um posicionamento revolucionário, partindo para a busca da implantação do comunismo via reformas econômico-sociais, sem conflagrar uma guerra-civil e dentro da legalidade constitucional. O objetivo passava a ser a conquista de um governo nacionalista e democrático através do processo eleitoral e da pressão de massas, excluída a via armada prevista anteriormente nos documentos do partido. Suas propostas, que não deixavam de ter um cunho "revolucionário", eram no sentido do anti-imperialismo e do reforço de um desenvolvimentismo de cunho nacional; da reforma agrária e do combate ao latifúndio; de uma política externa independente e da ampliação das liberdades democráticas, entre outras. Sua estratégia era a aliança com a burguesia nacional e as demais classes sociais em uma Frente Única, com a liderança do processo nas mãos da classe proletária. ${ }^{14}$

http://www.fgv.br/cpdoc/acervo/dicionarios/verbete-tematico/frente-de-mobilizacao-popular-fmp. Acesso em: 20 jun. 2017.

${ }^{10}$ Cf.: Reformas de Base. (Verbete). Disponível em http://www.fgv.br/cpdoc/acervo/dicionarios/verbetetematico/reformas-de-base. Acesso em: 20 jun. 2017.

${ }^{11}$ A expansão industrialista do pós Segunda Guerra chegou ao Brasil no governo de Juscelino Kubitschek, contribuindo para uma nova etapa na industrialização do país, com capitais europeus, japoneses e norteamericanos, aprofundando a nossa dependência ao capital internacional. MENDONÇA, Sonia Regina de. Estado e economia no Brasil: opções de desenvolvimento. Rio de Janeiro: Graal, 1985, p. 47-48.

${ }^{12}$ Entre os partidos, havia setores favoráveis a reformas, como a Ala Moça, do PSD, e a Bossa Nova, da UDN, que adotavam diversos pontos propugnados pela Frente de Mobilização Popular. GORENDER, Jacob. Combate nas Trevas. Op. cit., p. 51.

${ }^{13}$ FERREIRA, Jorge. O Partido Comunista Brasileiro e o governo João Goulart. Revista Brasileira de História, São Paulo, v. 33, n. 66, 113-134, 2013.

${ }^{14}$ Idem. 
Durante as fases do governo de João Goulart, o PCB foi mudando sua postura. Na fase do parlamentarismo, não chegava a críticas mais profundas devido à sua pouca capacidade de decisão, já que as políticas de governo eram decididas pelo governo parlamentar. Entretanto quando, em junho de 1962, ocorreu a renúncia do gabinete de Tancredo Neves, depois de nove meses no governo, o PCB pressionou Jango para que escolhesse um primeiro-ministro de esquerda, porém sem sucesso.

Com a vitória do presidencialismo em 1963, as críticas a Jango aumentaram. A maior crítica do PCB era sobre o fato de Jango permanecer com uma política de conciliação com as forças consideradas de direita, representadas principalmente pelo PSD. A estratégia do PCB era a mobilização dos movimentos sociais como forma de pressionar o parlamento a aprovar tais reformas, além da formação de um governo marcadamente de esquerda. Pretendia, inclusive, participar de uma frente única com a Frente de Mobilização Popular (FMP), formada por Brizola em 1962, reunindo diversos partidos, grupos e movimentos de esquerda. ${ }^{15}$

Prevendo a radicalização política, o deputado pelo PTB, San Tiago Dantas, de posição mais moderada, propunha outra coalizão política que isolasse a extrema direita, liderada por Carlos Lacerda, da União Democrática Nacional (UDN), e Ademar de Barros, do Partido Social Progressista (PSP) e aglutinasse um PTB, sem Brizola, o PSD e outros partidos mais ao centro do espectro político. Dantas ainda pretendia obter o apoio do PCB e de Miguel Arraes, governador de Pernambuco e maior liderança do Partido Socialista Brasileiro (PSB). Era a chamada Frente Progressista de Apoio às Reformas de Base.

Arraes preferiu continuar com a FMP e o PCB, apesar de inicialmente negociar o apoio. Pediu a inclusão ao programa da Frente Progressista da reforma agrária sem indenizações; a suspensão da remessa de lucros para o exterior e os pagamentos das dívidas com credores externos; estatização das empresas estrangeiras que atuavam nos ramos dos moinhos, fábricas de leite em pó e indústria farmacêutica; monopólio do câmbio pelo Banco do Brasil e das exportações do café; reajustes salariais pelos índices da inflação e participação dos sindicatos na indicação de diretores das empresas estatais; política externa independente, além da revogação de artigos da Lei de Segurança Nacional, reforma eleitoral, anistia aos sargentos que tomaram Brasília ${ }^{16}$ e a legalização do PCB, entre outras medidas que inviabilizaram os acordos no Congresso e azedaram a aliança com a Frente Progressista. ${ }^{17}$

\footnotetext{
${ }^{15} \mathrm{Na}$ FMP estavam representados os estudantes, com a União Nacional dos Estudantes (UNE); os operários urbanos, com o Comando Geral dos Trabalhadores (CGT), a Confederação Nacional dos Trabalhadores na Indústria (CNTI), o Pacto de Unidade e Ação (PUA) e a Confederação Nacional dos Trabalhadores nas Empresas de Crédito (CONTEC); os subalternos das Forças Armadas, como sargentos, marinheiros e fuzileiros navais por meio de suas associações; facções das Ligas Camponesas; grupos de esquerda revolucionária como a Ação Popular (AP), a POLOP (Organização Revolucionária Marxista Política Operária), o Partido Operário Revolucionário (Trotskista) (POR-T) e segmentos de extremaesquerda do PCB; bem como políticos do Grupo Compacto do PTB e da Frente Parlamentar Nacionalista (FPN), além dos nacional-revolucionários brizolistas. In: FERREIRA, Jorge. Leonel Brizola, as esquerdas e a radicalização política no governo Goulart (1961-1964). Nono Congresso Internacional da Brazilian Studies Association (BRASA), Tulane University, Nova Orleans, Louisiana - EUA, mar. 2008.

${ }^{16}$ Rebelião promovida por cabos, sargentos e suboficiais, sobretudo da Aeronáutica e da Marinha, em 12 de setembro de 1963, em Brasília, motivada pela decisão do Supremo Tribunal Federal (STF) de reafirmar a inelegibilidade dos sargentos para os órgãos do Poder Legislativo, conforme previa a
} 
Jango, vendo malograda a tentativa de Tiago Dantas, o aumento da resistência dos setores mais à direita ao seu programa de governo e, também, que não conseguiria o apoio do Congresso, aproximou-se da FMP e do PCB, assinalando a nova aliança no comício de 13 de março de 1964 na Central do Brasil, quando as reformas sociais foram lançadas publicamente.

Segundo Jorge Ferreira, a partir de então, o PCB passou de crítico a aliado do governo. ${ }^{18}$ Além do comício de 13 de março na Central do Brasil, outros sete estavam marcados para o mês de abril e seriam realizados nas cidades de Santos, Santo André, Salvador, Ribeirão Preto, Belo Horizonte e Brasília. O último foi marcado para o dia $1^{0}$ de maio na capital paulista, o que daria início a uma greve geral. A estratégia era pressionar o Congresso a aprovar as reformas de base a partir da mobilização das massas populares. Essa mobilização seria feita pela Frente Popular, que foi formada, sob a liderança de Jango, com a participação da CGT, da Frente Parlamentar Nacionalista, do PTB, dos setores mais à esquerda do PSD e mesmo da UDN, da Ação Popular, da UNE, do Comando dos Trabalhadores Intelectuais, além de outras entidades.

Entretanto, além das reformas de base, a lei de remessas de lucros pelas multinacionais para suas matrizes, que não podia exceder a $10 \%$ dos investimentos líquidos registrados, adotada pelo governo Jango, provocara forte reação dos interesses multinacionais e associados. O presidente pretendia também uma mudança nas diretrizes anteriores de industrialização que beneficiava multinacionais, fornecedoras de reduzido mercado de alto poder aquisitivo, para um modelo de estímulo às indústrias de porte médio e setores agrários que produzissem alimentos, vestuário e aparelhos eletrodomésticos básicos para um grande mercado de baixa renda.

Goulart estava se distanciando do passado populista que reconciliara as frações das classes dominantes e manipulara as classes trabalhadoras, retirando o Brasil da esfera de influência do capital transnacional, afastando o país de uma política externa alinhada aos EUA e apresentando características distributivas e desenvolvimentistas. Além disso, a espiral de greves da classe trabalhadora alarmava as classes médias. Assim, segundo Dreyfuss, o bloco multinacional associado preparou-se para restringir as demandas populares através de meios não políticos, articulando um bloco civil-militar de tendências cesaristas. ${ }^{19}$ Portanto, os grupos dominantes conservadores, compostos por empresários e latifundiários, ${ }^{20}$ apressaram-se em

Constituição de 1946. A revolta foi sufocada por tropas do Exército. Os prisioneiros, num total de 536, foram mandados para o Rio de Janeiro, sendo alojados num barco-presídio ancorado na Baía de Guanabara. Outros líderes do movimento foram detidos no Rio, em São Paulo e no Rio Grande do Sul. Em 19 de março de 1964, os 19 sargentos indiciados em inquérito policial-militar (IPM) foram condenados a quatro anos de prisão. Cf.: A Revolta dos Sargentos. (Verbete). Disponível em: http://cpdoc.fgv.br/producao/dossies/Jango/artigos/AConjunturaRadicalizacao/A_revolta_dos_sargentos. Acesso em: 20 jun. 2017.

${ }^{17}$ FERREIRA, Jorge. O Partido Comunista Brasileiro... Op. cit.

18 Idem.

${ }^{19}$ DREIFUSS, René Armand. 1964: A Conquista do Estado. Ação Política, Poder e Golpe de Classe. Petrópolis: Vozes, 1981, p. 130-135.

${ }^{20}$ TOLEDO, Caio Navarro de. $1964 \ldots$... Op. cit. René Dreyfuss chama esse grupo de conservadores de "interesses multinacionais e associados". Cf.: DREIFUSS, René Armand. 1964... Op. cit., p. 129. 
se aglutinar em torno dos militares anticomunistas para desfechar o golpe civil-militar, ${ }^{21}$ que procurava impedir essa ascensão social das camadas populares.

O golpe civil-militar ocorrido entre os dias 31 de março e $1^{0}$ de abril interrompeu os projetos de Goulart e das esquerdas, passando a haver perseguição de trabalhistas, comunistas e do movimento sindical. Os grupos opositores ao governo Goulart que pressionaram para a precipitação do golpe foram, principalmente, a UDN, setores das forças armadas, setores conservadores da Igreja Católica, proprietários rurais, a maior parte do empresariado nacional, investidores internacionais e parte da classe média. ${ }^{22}$

\section{O PCB e sua participação na organização dos trabalhadores}

Para melhor descrever a participação do PCB na organização dos trabalhadores, é importante voltar a $1947,{ }^{23}$ quando ocorreu a cassação do referido partido político, devido ao alinhamento do governo Dutra ao americanismo da Guerra Fria. Como consequência, o partido passou do pacifismo à pregação da violência revolucionária imediata.

O Manifesto de Agosto de 1950 criticava os grandes capitalistas brasileiros, igualandoos aos monopólios imperialistas. Entretanto, o Quarto Congresso do partido, de 1954, voltara a colocar a burguesia nacional na frente revolucionária ao mesmo tempo em que atacava Vargas como governo de traição nacional. Depois do suicídio de Vargas, considerado como provocado pela pressão do imperialismo norte-americano e do golpismo da direita, o PCB passou a adotar uma política de alianças com as forças consideradas progressistas, o que resultou no apoio às candidaturas de Juscelino Kubistchek, para presidente, e João Goulart, para vice-presidente, em 1955, e do general Henrique Teixeira Lott, para presidente, e

\footnotetext{
${ }^{21}$ Para Demian de Melo, a historiografia tem apresentado o termo "golpe civil-militar" e mesmo "ditadura civil-militar" para lembrar que parte dos civis apoiou o golpe e participou do processo político de 1964 e 1985. Entretanto, o autor ressalta que René Armand Dreifuss, historiador e cientista político uruguaio, em sua tese de doutorado, de 1981, intitulada 1964, a conquista do Estado, também afirma a participação de elementos "civis" que atuaram nos postos estratégicos daquele regime. Todavia, entendeos de forma bastante específica, como parte de uma elite organicamente ligada aos interesses do capital multinacional e associado, devendo esses civis serem chamados mais precisamente de empresários, ou, na melhor das hipóteses, de tecno-empresários. Dessa forma, se diferencia da concepção mais ampla em que a "sociedade brasileira" teria participado do golpe militar, como se essa visão difusa denotasse um amplo apoio e participação da sociedade ao regime militar. Para ele, então, uma ditadura empresarialmilitar foi implantada a partir de uma insurreição contrarrevolucionária das classes dominantes. Cf.: MELO, Demian Bezerra de. Ditadura "civil-militar"?: controvérsias historiográficas sobre o processo político brasileiro no pós-1964 e os desafios do tempo presente. Espaço Plural, ano XIII, n. 27, 39-53, $2^{\circ}$ sem. 2012.

22 DELGADO, Lucília de Almeida Neves. O Governo João Goulart e o golpe de 1964: memória, história e historiografia. Revista Tempo, Niterói (RJ), v. 14, n. 28, jun. 2010.

${ }^{23}$ Em reunião do dia 7 de maio de 1947, o TSE julgou procedentes as acusações contra o PCB por três votos contra dois, cancelando assim o seu registro. O desembargador Alceu Barbedo argumentou que, além da irregularidade dos estatutos, o PCB era um partido estrangeiro, apresentando como prova o seu nome: não era um Partido Comunista Brasileiro e sim um Partido Comunista do Brasil. Em 10 de maio, o ministro da Justiça, Benedito Costa Neto, determinou o encerramento das atividades do PCB. Cf.: Partido Comunista Brasileiro (PCB). $\quad$ (Verbete). Disponível em: http://www.fgv.br/cpdoc/acervo/dicionarios/verbete-tematico/partido-comunista-brasileiro-pcb. Acesso
} em: 20 jun. 2017. 
Goulart, para vice-presidente, em 1960, seguindo a linha de colaboração com a "burguesia nacionalista". ${ }^{24}$

A nova linha política saída do Quarto Congresso vinha de uma concepção elaborada no Sexto Congresso da Internacional Comunista de 1928 e apresentava uma proposta de revolução em duas etapas. A primeira etapa seria uma revolução nacional e democrática de conteúdo anti-imperialista e antifeudal, com a comunhão entre proletariado e burguesia nacionalista, sob a hegemonia do primeiro. A segunda era a revolução socialista. ${ }^{25}$ As lideranças de Luís Carlos Prestes e Giocondo Dias predominavam no partido e seguiam a linha da aliança estratégica com a burguesia nacional e as classes populares. Uma ala minoritária pregava a aliança apenas com as forças populares. Essa linha revolucionária defendia uma reforma estrutural do país, que ficou conhecida pela denominação de Reformas de Base.

Em agosto de 1961, o PCB encaminhou documentos para registro do partido no Tribunal Superior Eleitoral a fim de legalizá-lo. Com a intenção de se defender do motivo da cassação que sofrera em 1947, quando acusado de ser uma seção da Internacional Comunista e não um partido brasileiro, seu nome foi mudado para Partido Comunista Brasileiro. O pedido de registro não foi aceito e a facção dos estalinistas acusaram Prestes e seus seguidores de terem renegado o partido fundado em 1922 e criado um novo partido revisionista. Em fevereiro de 1962, na chamada Conferência Nacional Extraordinária do Partido Comunista do Brasil, PC do B, formalizou-se a cisão entre os estalinistas e aqueles a quem chamavam de revisionistas, por seguirem o PCUS agora sob a liderança de Nikita Kruschev, que havia criticado o autoritarismo do período estalinista. ${ }^{26}$

\footnotetext{
${ }^{24}$ GORENDER, Jacob. Combate nas Trevas. Op. cit., cap. 3.

${ }^{25}$ A partir do IV Congresso, O PCB tomou a resolução de ampliar o espectro de alianças contra as investidas do "imperialismo norte-americano". O partido intensificou suas alianças com outros setores militantes no meio operário, principalmente o setor nacionalista e progressista do PTB. A Declaração de Março de 1958 indicava para uma revolução brasileira em duas etapas: primeiro a democrática e nacional, com reformas estruturais como meio de intensificar o desenvolvimento capitalista, e depois a socialista. A partir desse momento, O PCB começou a trabalhar suas estratégias políticas abertamente, atuando em uma "legalidade de fato". Cf.: SANTANA, Marco Aurélio. Homens Partidos. Comunistas e Sindicatos no Brasil. São Paulo: Boitempo, 2001, p. 90-94.

${ }^{26} \mathrm{Na}$ década de 1950, o PCB deixou a orientação da violência revolucionária contra o governo de Eurico Gaspar Dutra, devido à cassação do partido, o que Gorender chamou de "extremismo ressentido", para defender uma posição pacifista anti-imperialista e com proposta de uma frente ampla democrática e nacional. A linha pacifista não fora aceita por todos os militantes, sendo um dos motivos que levaria à futura cisão. Outro motivo seria o fato de que o início da década de 1960 assistiu também à ruptura entre a União Soviética e a China comunista, precipitada pela recusa de Nikita Kruschev em fornecer a tecnologia da bomba atômica a Mao Tsé-Tung, e principalmente pela retirada de todos os técnicos soviéticos que vinham participando da modernização da economia chinesa. Uma das consequências dessa crise para o movimento comunista mundial foi a perda da hegemonia que mantinha a União Soviética na condução e orientação dos partidos comunistas. A partir desse momento, novos partidos comunistas surgiram no mundo sob a égide da China, que definia uma estratégia política mais agressiva, defendendo a luta armada como o único caminho para os países capitalistas atingirem o socialismo. Paralelamente a esses acontecimentos, em agosto de 1961 realizou-se uma conferência nacional do PCB, na qual ficou decidido que o partido passaria a se chamar Partido Comunista Brasileiro, para facilitar o registro no TSE. Os dirigentes comunistas, preocupados em legalizar novamente o partido, tinham a intenção de mostrar o caráter nacional da organização, já que um dos argumentos utilizados para o cancelamento do seu registro em 1947 fora o de que era de um partido vinculado à União Soviética, como o demonstrava o nome de Partido Comunista do Brasil. O grupo que fora afastado do Comitê Central durante o $\mathrm{V}$ Congresso se opôs a essa decisão e, nesse momento, a direção do partido decidiu expulsá-lo. Em fevereiro de 1962, o grupo liderado por João Amazonas, Maurício Grabois e Pedro Pomar convocou uma
} 
Durante o governo Jango, o sindicalismo se fortaleceu e se mobilizou de forma bastante significativa. ${ }^{27}$ Foram 430 greves deflagradas pelos sindicatos, entre 1961 e 1963, contra apenas 180 do período de Juscelino Kubitschek, entre 1958 e 1960, com grande destaque para a atuação do CGT - Comando Geral dos Trabalhadores. O CGT contava com a participação do $\mathrm{PCB}^{28}$ além de setores do PTB, e seguia uma linha nacional-desenvolvimentista. A disseminação das Ligas Camponesas ${ }^{29}$ pelo Nordeste e as promessas de reforma agrária pelo governo Jango, juntamente com a mobilização dos trabalhadores urbanos, eram muito temidas tanto por empresários, latifundiários e pelos militares, que acreditavam estar o país vivendo um descontrole social e político. Atribuíam a Jango o plano de tentar instituir uma "República sindicalista" no país. ${ }^{30}$

O trabalhismo, ${ }^{31}$ implantado por Getúlio Vargas e seguido por João Goulart e Leonel Brizola, via o Estado como protetor da classe trabalhadora, que deveria se integrar a um projeto nacional-desenvolvimentista em que a industrialização seria de interesse comum a burgueses e operários, sob a hegemonia política e ideológica dos primeiros. Assim, a essência do trabalhismo estaria na colaboração entre as classes e a manutenção da paz social. Entretanto, o crescimento da classe trabalhadora, juntamente com a industrialização, e sua maior conscientização como classe, devido ao avanço do sindicalismo varguista, acabou

conferência nacional extraordinária de oposição ao "partido prestista" e fundou uma nova organização, com o nome de Partido Comunista do Brasil, adotando a sigla PCdoB e vinculando sua orientação à política da China Popular. O PC do B retomou o programa do IV Congresso, repelindo a luta pelas reformas de base e reivindicando a instauração pela violência revolucionária de um governo popular revolucionário anti-imperialista, antilatifundiário e antimonopolista. Cf.: Partido Comunista Brasileiro (PCB). (Verbete). Op. cit.; GORENDER, Jacob. Combate nas Trevas. Op. cit., p. 34; SILVEIRA, Éder da Silva. Dissidência comunista: da cisão do PCB à formação do PCBR na década de 1960. Anos 90, Porto Alegre, v. 20, n. 37, 291-322, jul. 2013.

${ }^{27}$ Após os expurgos sofridos pelo governo Dutra, os sindicatos, sob o apoio do vice-presidente João Goulart, voltaram a se organizar e a buscar maior autonomia frente ao Estado. A classe trabalhadora industrial havia se multiplicado e se achava concentrada em termos regionais. Dezenas de congressos trabalhistas foram organizados na década de 1950. Começava a se manifestar uma crescente participação popular na política. Cf.: DREIFUSS, René Armand. 1964... Op. cit., p. 128-129.

${ }_{28}$ Entre 1954 e 1964, os comunistas participaram intensamente do movimento sindical, em parceria ou isolados. Apostaram na criação de organizações superiores aos sindicatos dos trabalhadores como forma de buscar a unificação das forças operárias, estando entre elas a PUA e o CGT. A tática era explorar os espaços permitidos legalmente e extrapolar os limites legais quando possível. Além disso, objetivando democratizar as relações entre trabalhadores e sindicatos, O PCB atuou na formação de "conselhos sindicais de empresa", que deveriam servir de instrumento de pressão sobre as lideranças sindicais. De acordo com Santana, como organizaram greves em contraposição à postura conciliadora da liderança sindical comunista-trabalhista, houve, um descolamento entre bases e lideranças no plano organizacional. O CGT tinha o apoio de quatro das seis confederações dos trabalhadores, sendo elas CNTI, CONTEC, CNTMFA e a CONTAG, o que demonstrava a força política dos comunistas. Cf.: SANTANA, Marco Aurélio. Homens Partidos. Op. cit., p. 89; 100-102; 128.

${ }^{29}$ As ligas camponesas foram associações de trabalhadores rurais criadas inicialmente no estado de Pernambuco, posteriormente na Paraíba, no estado do Rio de Janeiro, Goiás e em outras regiões do Brasil, que exerceram intensa atividade no período que se estendeu de 1955 até a queda de João Goulart em 1964. Cf.: Ligas Camponesas. (Verbete) Disponível em: http://www.fgv.br/cpdoc/acervo/dicionarios/verbete-tematico/ligas-camponesas. Acesso em: 20 jun. 2017.

${ }^{30}$ TOLEDO, Caio Navarro de.1964... Op. cit.

${ }^{31}$ Segundo Angela de Castro Gomes, o trabalhismo seria o processo de formação da classe trabalhadora e sua emergência como ator político. GOMES, Angela de Castro. A Invenção do Trabalhismo. Rio de Janeiro: Ed. FGV, 2005, p. 10. Para Jacob Gorender seria a proteção aos trabalhadores por um Estado paternalista em seus litígios com seus patrões, sendo a industrialização de interesse comum a burgueses e operários. GORENDER, Jacob. Combate nas Trevas. Op. cit., p. 16. 
levando a reivindicações econômicas e ao acirramento da luta de classes. Esse conflito classista também se estendeu ao campo, pois a nova etapa da industrialização provocara reformas também no setor rural, afetando os camponeses na forma de exploração salarial ou mesmo no desalojamento de suas posses de terras. Essa situação levou a choques entre camponeses e fazendeiros. Diante desse contexto, os camponeses também ampliaram sua consciência de classe e formaram sindicatos, sendo um dos mais expressivos a Liga Camponesa, em Pernambuco. ${ }^{32}$

O PCB do pós Segunda Guerra, por sua vez, acreditava na burguesia nacional e recomendava aos trabalhadores 0 entendimento com os patrões para 0 bem do desenvolvimento nacional. Entre 1946 e 1964, o PCB era a força de esquerda mais organizada, com grande influência entre operários, camponeses, estudantes e movimentos antiimperialistas. Para Santana, o PCB vinha em um movimento de crescimento político contínuo e, em 1962, já contava com aproximadamente trinta mil membros. ${ }^{33}$

Na região do vale do Paraíba fluminense, O PCB atuou fortemente entre as organizações operárias. Durante a construção da Companhia Siderúrgica Nacional, seus trabalhadores fundaram (em 1945) a Associação Profissional dos Trabalhadores nas Indústrias Metalúrgicas de Barra Mansa. O PCB que, desde 1943, vinha iniciando sua reconstrução política, participara intensamente da criação dessa entidade e também de células políticas na região para atuar no movimento operário. Desde o início, a associação dos trabalhadores metalúrgicos sofreu forte fiscalização e controle do Departamento de Imprensa e Propaganda, das Forças Armadas e do Departamento Federal de Segurança Pública, devido à importância econômica da região. O PCB atuava nessa área com liberdade no período do imediato pós-guerra. Apesar do PTB ter crescido fortemente no complexo industrial que tinha a CSN como seu carro-forte, devido a sua identificação com o nacional-trabalhismo getulista em meio ao operariado nascente, o PCB era o partido com maior apoio popular, com cerca de $60 \%$ do eleitorado. ${ }^{34}$ O PCB tinha à época uma sede no bairro Niterói, no então distrito de Volta Redonda. ${ }^{35}$

Os comunistas, na década de 1950, assumiram a liderança de movimentos sindicais, o que teria ganhado força com a Greve dos 300 mil entre março e abril de 1953 e que culminaria com o movimento operário-sindical em 1964. Haveria ainda aproximação entre os comunistas e a ala esquerda do PTB, mas também houve muitas disputas entre comunistas e trabalhistas pelo controle das direções sindicais. Apesar de possuírem os mesmos interesses, ou seja, a defesa da industrialização nacional, do intervencionismo estatal, do nacionalismo econômico e emancipação do país em relação à classe latifundiária, as forças imperialistas e os liberalconservadores, comunistas e trabalhistas concorriam entre si pela disputa da hegemonia sobre os movimentos dos trabalhadores. O trabalhismo varguista era visto pelos comunistas como

\footnotetext{
32 GORENDER, Jacob. Combate nas Trevas. Op. cit., cap. 2.

33 SANTANA, Marco Aurélio. Homens Partidos. Op. cit., p. 98.

${ }^{34}$ BEDÊ, Edgard. A Formação da Classe Operária em Volta Redonda. Volta Redonda (RJ): Nova Gráfica, 2011 , p. $65-66 ; 69$.

${ }^{35}$ Volta Redonda se tornaria independente de Barra Mansa apenas em 1954.
} 
reformismo da burguesia nacional. Entretanto, por vezes, o PCB apoiou alianças com o PTB, e mesmo o PSD, como estratégia para disputar o controle dos sindicatos.

No vale do Paraíba fluminense, o PTB e o PCB disputavam o controle da direção do Sindicato dos Metalúrgicos e do movimento operário. Enquanto os comunistas queriam instrumentalizar o sindicato para a politização dos operários frente à exploração do capital, os trabalhistas o queriam como instrumento de pressão sobre as negociações salariais e condições de trabalho, ampliando a política de bem estar social. As principais lideranças do Sindicato dos Metalúrgicos foram os trabalhistas Othon Reis Fernandes (1959/1961) e Samuel de Paula Reis (1961/1963) e os comunistas Nestor Lima (1955/1957) e João Alves dos Santos Lima Neto $(1963 / 1964) .{ }^{36}$

Sob a gestão do comunista Nestor Lima (1955 a 1957) no Sindicato dos Metalúrgicos, esta entidade ganhou maior combatividade no confronto grevista com indústrias privadas da região, preservando-se a CSN, que deveria ser poupada, pois era considerada pelos comunistas como de interesse do povo brasileiro. Tanto para comunistas como para os trabalhistas, a CSN deveria ser poupada de greves devido a sua importância para a independência econômica nacional frente às forças externas imperialistas e às internas entreguistas que queriam aprofundar a dependência econômica nacional. Lima Neto, por sua vez, teria uma postura mais oposicionista em relação à direção da CSN, denunciando chefias autoritárias e o atrelamento da direção sindical à CSN, colocando-se em contraponto a Othon Reis, com posição mais conciliatória com a empresa. Com a liderança de Lima Neto, pela primeira vez uma direção do Sindicato dos Metalúrgicos ameaçou uma greve na CSN, reivindicando um aumento imediato de $50 \%$ devido à desvalorização salarial causada pelo aceleramento da inflação. ${ }^{37}$

Além da participação efetiva nos sindicatos urbanos, O PCB também tinha influência forte em 21 das 42 federações de trabalhadores rurais, formando a primeira diretoria da Confederação Nacional dos Trabalhadores na Agricultura (Contag), e também no meio estudantil. Comunistas e trabalhistas conquistaram posições de direção em federações e confederações. Em 1961, greves se espalharam pelo país. A questão agrária também se radicalizou com choques armados e invasões de fazendas. Em novembro de 1961, o Congresso de Lavradores e Trabalhadores Agrícolas, em Belo Horizonte, com predomínio de comunistas e da Liga Camponesa, pretendia radicalizar a reforma agrária. ${ }^{38}$

Após o golpe, as lideranças que apoiavam Jango foram perseguidas, cassadas, presas e muitos se exilaram. Ao acesso à direção sindical foi imposta a exigência de avaliação pelo Ministério do Trabalho e pela polícia política. O Instituto Nacional de Previdência Social (INPS) passou a concentrar todos os recursos previdenciários, antes dispersos pelos institutos de previdência, e sua direção não se faria mais compartilhada com os trabalhadores, mas por

\footnotetext{
${ }^{36}$ Entre 1951 e 1955, o PSD predominou nas direções do Sindicato dos Metalúrgicos da região, provavelmente como resultado das repressões e intervenções exercidas anteriormente pelo governo Dutra sobre os sindicatos. Cf.: BEDÊ, Edgard. A Formação da Classe... Op. cit., p. 104;158; 162.

37 Idem.

${ }^{38}$ GORENDER, Jacob. Combate nas Trevas. Op. cit., cap. 6.
} 
membros indicados pelo governo. As greves deveriam se limitar à cobrança de salários atrasados. O Fundo de Garantia do Tempo de Serviço (FGTS) terminava com a estabilidade no emprego, pois até então a Consolidação das Leis do Trabalho (CLT) assegurava a estabilidade ao trabalhador do setor privado que completasse 10 anos em serviço para a mesma empresa, o que fora derrogado pela criação daquele instituto, proporcionando uma maior rotatividade dos trabalhadores nas empresas, dificultando uma ação sindical mais combativa. Os sindicatos passaram a ter por função o controle sobre os trabalhadores e prestação de atividades assistencialistas. ${ }^{39}$

\section{Brizola e os Grupos de Onze}

Leonel de Moura Brizola foi uma das grandes lideranças trabalhistas do período anterior ao golpe civil-militar. Brizola liderava o grupo nacional-revolucionário do PTB. Destacou-se na política quando era governador do Rio Grande do Sul, nacionalizou empresas norte-americanas de energia e comunicação e criou 680 mil vagas em escolas estaduais. ${ }^{40} \mathrm{Com}$ a Campanha da Legalidade, ganhou projeção nacional ao enfrentar grupos civis e militares da direita que não aceitavam que Jango assumisse o governo deixado por Jânio Quadros.

Brizola não conseguira fazer o seu sucessor no Rio Grande do Sul, sendo sucedido por Ildo Meneghetti, que se tornou um dos esteios do golpe de 64. Entretanto, conseguiu ser eleito deputado federal pelo estado da Guanabara, em 1962, quando se candidatou a convite de José Gomes Talarico, então secretário da comissão executiva. Talarico tinha como objetivo fortalecer a legenda contra a UDN e Carlos Lacerda. Para Brizola, era a oportunidade de se lançar futuramente à presidência do país por um estado de maior projeção nacional do que o Rio Grande do Sul, pois, através da Rádio Mayrink Veiga, atingiria o território nacional, popularizando os temas sobre a reforma agrária e a luta contra o imperialismo. ${ }^{41}$

Em fins de novembro de 1963, Brizola começou a formar os Grupos de Onze. Esses grupos deveriam ser compostos da seguinte maneira: primeiro duas ou três pessoas, em comum acordo, convidariam outros colegas até formarem um grupo de onze membros. A seguir, lavrariam a ata de fundação com a assinatura de todos. Desse modo, haveria a concordância com o manifesto que acompanhava o modelo de ata. Depois, o grupo escolheria um chefe e um substituto eventual. Ao final, comunicariam, por carta ou telegrama (de

\footnotetext{
39 SANTANA, Marco Aurélio. Ditadura Militar e resistência operária: O movimento sindical brasileiro do golpe à transição democrática. Revista Política e Sociedade, v. 7, n. 13, 279-309, out. 2008.

${ }^{40}$ Brizola executara a encampação da Companhia Elétrica Rio-Grandense (CEERG), subsidiária da multinacional Bond andShare (empresa da American \&Foreing Power - Amforp), em maio de 1959. Em fevereiro de 1962, o governo Brizola desapropriou, sem indenização, a companhia telefônica de Porto Alegre, subsidiária da ITT norte-americana. Promoveu, ainda, a fundação do Movimento dos Agricultores Sem Terra (MASTER), que organizou acampamentos de camponeses em terras improdutivas e as desapropriou. In: BRANDALISE, Carla; HARRES, Marluza Marques. Brizola e os comunistas: os Comandos Nacionalistas na conjuntura do golpe civil-militar de 1964. Revista Antíteses, v. 8, n. 15, 178-202, nov. 2015.

${ }^{41}$ Ibidem, p. 185.
} 
preferência entregando pessoalmente), a formação do grupo ao deputado Leonel Brizola, na sede da rádio Mayrink Veiga, no Rio de Janeiro, constando o endereço para correspondência.

O objetivo da criação desses grupos era, segundo Brizola, organizar a população para defender seus interesses contra aqueles que pretendiam "garrotear as nossas conquistas democráticas" diante de momentos cruciais que estariam em breve por vir. Brizola parecia acreditar que as condições para uma ruptura no sistema político estariam dadas e que ela logo aconteceria "na hora do desfecho que se aproxima". ${ }^{42}$

O número de 11 (onze) era uma alusão ao time de futebol, cultura arraigada entre a população brasileira, em que cada um tem uma função e um líder, o capitão do time. Também se tratava de um quantitativo muito reduzido, tornando-se mais fácil e rápido sua formação e ação. Para a vitória das classes populares, "à medida que a crise brasileira se aproxima do seu desfecho", era necessário que todos agissem de forma organizada e coordenada com um "trabalho em equipe". Esses grupos, que deveriam ser reunidos nos mais diversos locais, como em meio aos vizinhos, nas fábricas, nos escritórios, na classe social a que se pertencia, na lavoura ou no campo, teriam suas atividades coordenadas em nível local, regional e nacional. Cerca de 60 a 70 mil militantes se organizaram nos Grupos de Onze. ${ }^{43}$

A estratégia de formação dos Grupos de Onze era organizar a defesa da democracia, das reformas de base e combater o imperialismo. Não havia nenhuma referência ao uso de armas ou instruções sobre formação de guerrilhas. Pelo menos em tese, esses grupos pretendiam fazer pressão popular pelas reformas de base, desenvolvendo a consciência política da população através de debates em torno da reivindicação dos direitos básicos. ${ }^{44}$

Em seu programa na Rádio Mayrink Veiga, Brizola lia nome por nome daqueles que haviam se inscrito nos comandos dos Grupos de Onze. Essa publicização constante da arregimentação de novos membros seguidores de Brizola provocou forte repercussão entre as forças contrárias ao brizolismo. Por isso, forte repressão se abateu sobre os correligionários dos comandos logo após o golpe de abril de 1964.

Para Prestes, os comandos brizolistas tinham o objetivo de promover a luta armada, mas sem condições para isso. Acreditava que Brizola era muito radical e voluntarista em sua disputa pelo poder com Jango. Além disso, Prestes se ressentia de que, mesmo entre comunistas, muitos se alistaram nos Grupos de Onze, o que ele acreditava ser uma aposta errada, pois achava que deveria ser feito um trabalho de arregimentação em meio aos militares, uma vez que eram mais preparados para a luta armada, caso ela fosse necessária.

Após o golpe, muitos apoiadores do governo Goulart foram acusados de participar dos Grupos de Onze e, por isso, sofreram IPM (Inquérito Policial Militar), foram presos, perderam seus empregos e foram marginalizados pela sociedade com a pecha de subversivos.

\footnotetext{
${ }^{42}$ FERREIRA, Jorge. Leonel Brizola, as... Op. cit.

${ }^{43}$ Idem.

${ }^{44}$ BRANDALISE, Carla; HARRES, Marluza Marques. Brizola e os comunistas... Op. cit., p. 185-186.
} 


\section{O $1^{\circ}$ Batalhão de Infantaria Blindada de Barra Mansa}

A instalação da Companhia Siderúrgica Nacional (CSN), na década de 1940, no distrito de Volta Redonda (pertencente ainda ao município de Barra Mansa) foi fundamental para a consolidação da industrialização de base no país. Devido à sua importância o distrito se tornou área de segurança nacional e, como consequência, no ano de 1950, o 10 Batalhão de Infantaria Blindada foi instalado de forma provisória em Barra Mansa.

Desde o início, era função do 10 BIB manter a segurança do complexo industrial que havia entre Barra Mansa e Volta Redonda e, principalmente, da CSN, a maior siderúrgica da América Latina, fundamental para a estratégia de desenvolvimento econômico do país. No primeiro momento, o $1^{0}$ BIB contava com apenas uma companhia. Depois, em 1955, já instalado de forma definitiva em um antigo armazém regulador de café, passou a contar com duas companhias. Antes disso, desde o início do século XX já havia um Tiro de Guerra e um Batalhão de Caçadores havia sido implantado quando do início da construção da CSN. ${ }^{45}$

Para cumprir sua missão de segurança da região, o 10 BIB desenvolveu uma política de aproximação de autoridades civis, escolas e, principalmente, de patrulha policial e repressão a movimentos grevistas dos trabalhadores. Em Volta Redonda, casas foram cedidas pela CSN a militares do 10 BIB para que eles conhecessem os hábitos e modos de vida dos habitantes para melhor controle sobre a população local.

Em 1956, uma tentativa de greve dos metalúrgicos de Barra Mansa e Volta Redonda foi rechaçada pelo $1^{\circ}$ BIB. Em 1957, soldados desse batalhão tinham a incumbência de evitar qualquer perturbação da ordem por grevistas durante a inauguração de uma usina Eletrolítica em Volta Redonda. Em 1963, foi a vez de garantir o funcionamento das usinas de leite da região, ameaçadas de paralisação pelos seus trabalhadores. Em 1964, antes do golpe militar de abril, o $1^{\circ}$ BIB garantia a proteção e funcionamento da usina de Ribeirão das Lages, também ameaçada de paralisação por grevistas.

No dia do golpe, em 10 de abril, o $1^{\circ}$ BIB participou da repressão à tentativa de greve na CSN em resistência ao golpe. Havia um Plano de Segurança da Companhia que foi logo colocado em prática por sua diretoria industrial, setor ligado aos militares, promovendo a prisão de vários líderes grevistas. Na verdade, desde 1942, havia uma polícia secreta na CSN que investigava cada seção da usina e, até mesmo, o sindicato. Essa polícia teve presença ativa durante o golpe militar, uma vez que prestava informações ao BIB sobre supostos opositores ao regime. ${ }^{46}$ Além de sua atuação junto à CSN, seguindo a ordem de combater os seguidores do governo de João Goulart, o 10 BIB efetuou prisão e abriu inquéritos para investigar a vida política de diversas pessoas em Barra Mansa, Volta Redonda, Barra do Piraí e Piraí.

\footnotetext{
${ }^{45}$ A Voz da Cidade, Barra Mansa (RJ), 21 nov. 1970. Acervo do jornal A Voz da Cidade, Barra Mansa (RJ). ${ }^{46}$ BEDE, Edgard. Relatório da Comissão Municipal da Verdade D. Waldyr Calheiros. Volta Redonda: Câmara Municipal, 2015.
} 
Já em 1965, com o intuito de se preparar melhor para a segurança e repressão aos movimentos populares na região, o $1^{\circ}$ BIB teve um incremento de suas instalações e de seu contingente de efetivos. Em 1968, devido às diversas manifestações contra o regime militar ocorridas nas principais cidades do país, o $1^{\circ}$ BIB entrou em prontidão para enfrentar possíveis guerrilhas da oposição. Como era um órgão de repressão, durante a ditadura militar, diversos presos políticos passaram pelo quartel do $10 \mathrm{BIB}$, entre os quais líderes sindicais ligados à Companhia Siderúrgica Nacional, jovens estudantes e militantes de esquerda, assim como operários, pessoas ligadas a movimentos sociais e outros que pertenciam à Juventude Operária Católica (JOC). Muitos foram ali presos e torturados com choques elétricos, agressões físicas e demais formas. ${ }^{47}$ Após a denúncia de que soldados haviam sido torturados e mortos sob a acusação de tráfico de drogas naquele local, no dia 21 de setembro de $1972,{ }^{48}$ o Ministro do Exército resolveu transformar o $1^{\circ}$ BIB no $22^{\circ}$ Batalhão de Infantaria Motorizada, subordinando-o à $1^{\text {a }}$ Brigada de Infantaria Motorizada da Vila Militar da Guanabara. ${ }^{49}$

O Batalhão Militar foi presença marcante na vida dos municípios de Barra Mansa, Volta Redonda, Barra do Piraí e Piraí. Ali, ao completarem 18 anos, prestaram serviço militar os conscritos da região, que deveriam adotar os valores patrióticos militares ensinados naquela instituição. Seus comandantes tinham presença constante em eventos públicos, como inaugurações de obras públicas e de empresas privadas, e eram alvo de homenagens dos prefeitos e vereadores.

Mais tarde, na década de 1990 (mais especificamente em 28 de dezembro de 1992), o local foi transformado em Tiro de Guerra e, já na década de 2000, foi adquirido pela prefeitura de Barra Mansa e se tornou um local de recreação e sede da Guarda Municipal, adotando o nome de Parque da Cidade. Atualmente, o Ministério Público Federal pleiteia para o local um Centro de Memória da Ditadura. ${ }^{50}$

\section{O Inquérito Policial Militar contra os Comunistas}

Para entendermos melhor o que ocorria, voltaremos a abril de 1964 quando, por meio da portaria no 1 , de 14 de abril, o Comando Supremo da Revolução, delegou poderes para a instalação de Inquéritos Policiais Militares (IPM) ${ }^{51}$ com o objetivo de reprimir os grupos políticos que apoiaram o governo de João Goulart. Sob o comando do coronel Nilo de Queiróz

\footnotetext{
${ }^{47}$ BEDE, Edgard. Relatório da Comissão.

${ }^{48}$ SERBIN, Kenneth. Diálogos na Sombra: Bispos e Militares, Tortura e Justiça Social na Ditadura. São Paulo: Companhia das Letras, 2001.

${ }^{49}$ A Voz da Cidade, Barra Mansa (RJ), 19 set. 1972. Acervo do jornal A Voz da Cidade, Barra Mansa (RJ).

${ }^{50}$ Termo de Ajustamento de Conduta (TAC), celebrado entre o Ministério Público Federal e a Prefeitura Municipal de Barra Mansa, assinado em 24 de novembro de 2016.

${ }^{51}$ Inquéritos Policiais Militares foram instituídos pelo Ato Institucional $n^{\circ} 1$ e regulamentados pelo decreto-lei 53.897 de 27 de abril de 1964 e se constituíam em mecanismos legais de investigação de atividades subversivas e eliminação do considerado "inimigo interno" do regime, em mãos das Forças Armadas. Cf.: ALVES, Maria Helena Moreira. Estado e Oposição no Brasil (1964-1984). Petrópolis - RJ: Vozes, 1985, p. 56.
} 
Lima (então comandante do $1^{\circ}$ BIB), a partir de maio daquele ano, começaram as inquirições. O encarregado pelo IPM era o General de Divisão Hugo Panasco Alvim, mas o IPM foi presidido pelo major Mito Martins Ribeiro. ${ }^{52}$

No total, sessenta e duas pessoas foram interrogadas e denunciadas, entre integrantes e simples simpatizantes que contribuíam financeiramente para o PCB e sindicalistas. Da lista, constavam também nomes de altos membros do PCB, como Luís Carlos Prestes, e também do PC do B, como Lincoln Cordeiro Oest, Maurício Grabois e Pedro Pomar, por suas incursões na região. Além desses, Leonel Brizola também estava incluído no IPM por ser responsável pela formação dos Grupos de Onze. ${ }^{53}$

De acordo com os autos do inquérito, o depoimento de Waldemar de Carvalho Argollo, ${ }^{54}$ um dos membros do PCB, revelava que ele próprio, Oswaldo Carminatti, ${ }^{55}$ Ceciliano de Souza Filho (vulgo carioca), Dorvano Fabiano, Juracy de Souza, um funcionário da Companhia Nestlé (vulgo Nico), Candido Pereira da Silva, Paulo Alfaiate, José Delgado Cortez (vulgo Rodrigues) faziam parte do comitê municipal de Barra Mansa. Esse comitê era constituído por um Secretariado composto por 3 membros, que seriam Carminatti, Juracy e Dorvano, e uma comissão de finanças para a arrecadação de contribuições, composta por novamente Carminatti e Paulo Alfaiate. A composição das células-base em Barra Mansa tinha a seguinte organização: a Base-Centro, no centro da cidade, composta por José Delgado Cortez, Ceciliano de Sousa Filho, Paulo Alfaiate e Waldemar de Carvalho Argolo; a Base-Saudade, no distrito de mesmo nome, composta por Pernambuco e Padeiro; e Base-Júlio Cajazeiras, com sede no escritório de Carminatti, composta por este, Juracy e Dorvano. O escritório de Carminatti se situava à rua Dr. Mário Ramos, no 58, sala 105.

O comitê municipal recebia ordens do comitê estadual, via Maurício Grabois, uma das lideranças nacionais do PC do B, que fora substituído por Alcides Rodrigues Sabença. Em seguida, Sabença também foi substituído. Em seu lugar assumiu Feliciano Eugenio Neto. De acordo com o depoimento de Alcides Sabença, também faziam parte Paulo Alves Pereira, José Hugo Milan e José Maria Cordeiro. Roberto Ribas, motorista do posto de automóveis do Bar Azul, também era membro do PCB na cidade. Importa lembrar que, naquele momento, Barra Mansa já tinha uma Delegacia de Ordem Política e Social.

Cada membro contribuía mensalmente com um valor para o partido. O comitê estadual, em Niterói, recebia 2 mil cruzeiros do comitê municipal, contribuição obrigatória. Mensalmente os membros do comitê municipal tinham a obrigação de comparecer na Base-Centro. Esse comitê estadual era composto por Rubem Wanderley, José Hugo Milan, Feliciano Eugênio Neto, Alcides Sabença, Nilo (vereador em Nova Iguaçu) e Nilo Canela.

\footnotetext{
${ }^{52}$ IPM - PCB 7.478/64, Arquivo Brasil Nunca Mais - BNM 116, p. 31-32.

${ }^{53}$ Entretanto, o IPM não faz distinção entre os membros do PCB e do PC do B (e mesmo trabalhistas), considerando a todos como comunistas, identificando apenas as linhas russa (PCB) e chinesa (PC do B) as quais pertenciam.

${ }^{54}$ Depoimento de Waldemar de Carvalho Argollo, em interrogatório datado de 1 de maio de 1964 . Autos do IPM- PCB 7.478/64, p. 45 e ss.

${ }_{55}$ Carminatti, apesar de membro do PCB desde 1957, elegeu-se vereador pelo PSD. Autos do IPM- PCB $7.478 / 64$, p.5.
} 
O comitê de Volta Redonda era composto por Feliciano Eugênio Neto, Eurípedes Estrela, Israel Santana, Luís Ferreira Brum, Silvestre Pereira Rosa, Antônio Rocha Machado e Rubem Machado (falecido). Feliciano, que dirigia o comitê de Volta Redonda, também fazia a ligação entre os comitês de Barra Mansa e Volta Redonda, depois substituído por José Hugo Milan. Milan fora assessor sindical no Estado do Rio de Janeiro no governo Celso Peçanha e também secretário do Sindicato dos Rodoviários de Barra Mansa e Volta Redonda.

Segundo o depoimento de Alcides Rodrigues Sabença, ${ }^{56}$ em Volta Redonda os comunistas se reuniam no Edifício Labrud, no escritório de Silvestre Pereira, onde participavam, além dos elencados acima, Joaquim Lorenço de Almeida, Lindolfo Hil, Edil Américo Duarte, Argemiro da Costa Ribeiro, José Roque Moreira, Anaximandro Rattes, dentre outros. Outro membro do PCB em Volta Redonda era Ildefonso Jorge de Aquino e Silva, proprietário e redator-chefe do jornal $A$ Chibata, órgão do partido em Volta Redonda. ${ }^{57}$ Sua tipografia também produzia boletins e outros diversos para o Sindicato dos Metalúrgicos, sob a presidência do comunista João Alves dos Santos Lima Neto.

Como o PCB estava na ilegalidade, o Partido Social Trabalhista (PST) cedera a legenda aos candidatos comunistas em troca do apoio a Tenório Cavalcanti ao governo do estado do Rio de Janeiro. Carminatti, então, teria entrado em contato com Tenório e Luís Guimarães, presidente nacional do PST, para reestruturar o diretório deste partido em Barra Mansa, que passou a ter José Maria Cordeiro como presidente, o próprio Argollo como primeiro secretário e Carminatti como segundo secretário. Carminatti, Candido da Silva, Ceciliano, Dorvando e Argollo participaram como candidatos a vereador por este partido, mas nenhum deles conseguiu se eleger. Sendo assim, abandonaram o partido, que servia apenas como fachada para os comunistas.

Argollo que, por influência de Anaximandro Rattes, se filiara à linha comunista chinesa, majoritária em Barra Mansa, distribuía o jornal A Classe Operária, órgão oficial do PCB. Além desse periódico, os membros do partido deveriam orientar suas ações pelo jornal Novos Rumos. José Hugo Milan e Carminatti atuaram no campo, onde organizaram as Ligas Camponesas no bairro Colônia Santo Antônio, em Barra Mansa. Entretanto, não lograram êxito devido à repressão empreendida pelo10 BIB.

De acordo com o depoimento de Juracy Vieira de Souza, ${ }^{58}$ que ingressara no PCB em 1958, as reuniões do partido em Barra Mansa ocorriam no escritório de Carminatti e eram semanais. As reuniões eram dirigidas por elementos de fora que traziam orientações do

\footnotetext{
56 Interrogatório de Alcides Rodrigues Sabença, datado de 9 de junho de 1964. Autos do IPM- PCB $7.478 / 64$, p. 244 e ss. Ex-deputado federal pelo PCB, seria adepto da linha russa, minoritária no PCB de Barra Mansa. Autos do IPM- PCB 7.478/64, p.10.

57 Entretanto, Ildefonso afirmou em depoimento que o jornal era democrático, apenas tratando de problemas municipais e não era financiado por qualquer órgão, a não ser durante o governo de Nelson Gonçalves, quando fora órgão oficial da prefeitura de Volta Redonda, recebendo 15 mil cruzeiros mensais. O jornal teria uma tiragem de 800 exemplares. Ao mesmo tempo, admitiu que sua tipografia imprimia panfletos e manifestos dirigidos aos trabalhadores. Interrogatório de Ildefonso Jorge Aquino e Silva, datado de 7 de maio de 1964. Autos do IPM- PCB 7.478/64, p.106 e ss.

${ }^{58}$ Interrogatório de Juracy Vieira de Souza, datado de 3 de maio de 1964. Autos do IPM- PCB 7.478/64, p. 57 e ss.
} 
partido para cada um deles. José Milan era o elemento mais atuante e de ligação entre as cidades, agindo no meio operário e agrícola, com ligações com a SUPRA. ${ }^{59}$ Seus companheiros de partido eram Antônio da Rocha Machado, ${ }^{60}$ Dorvano Fabiano, Edil Américo Duarte, Brasil Diogo e Silvestre Rosa.

Juracy de Souza, que participara do Grupo dos Onze por intermédio de Pedro Silva, líder da bancada do PTB de Barra Mansa na Câmara dos Vereadores, liderava esses conselhos brizolistas na cidade. Pedro Silva teria recebido de Mozart Mendes do Prado uma lista para ser preenchida por elementos que desejassem constituir os Grupos de Onze. Teria recebido também um folheto explicativo de como agir para a constituição dos grupos. Quando estava na prefeitura, teria colhido a primeira assinatura de Hélio Couto. Este, por sua vez, chamara um colega, conhecido por Peixoto, que também assinara a lista. No mesmo dia, Juracy Vieira da Silva também assinara a lista. Outras pessoas, entre elas José Hugo Milan, que sabia serem comunistas, passaram a procurá-lo. Segundo as instruções, os integrantes do grupo escolheriam um líder e fariam a comunicação por carta ou telegrama ao Sr. Leonel Brizola, endereçada à Rádio Mayrink Veiga. A sede do grupo seria alternada entre as casas dos companheiros, que deveriam prestar atenção à Rádio a partir das $22 \mathrm{~h}$ e 30 minutos das sextas-feiras. Havia no folheto um espaço com os seguintes dizeres: "EU.................LÍDER ELEITO PELOS DEMAIS COMPANHEIROS, RESIDENTE À............, TELEFONE.............". ${ }^{61}$

Ainda segundo Juracy de Souza, ${ }^{62}$ Luís Carlos Prestes estivera em Volta Redonda para apoiar as atuações do partido na cidade. Recebera um almoço no Hotel Brasil em sua homenagem, quando compareceram Geraldo Leal Ribeiro, Silvestre Rosa, Anita Leocádia Prestes, Ermínio de Souza Cruz Filho, Othon Reis Fernandes, Anarcharssis Rattes, Anaximandro Rattes, Ceciliano, Carminatti, Dercides Monteiro Guimarães. O professor Brasil Lul Diogo teria redigido uma minuta de um manifesto ao povo sobre uma pretendida decretação de estado de sítio em outubro de 1963. Juracy afirmara que conhecera Prestes na residência de Joaquim Lourenço de Almeida, em Volta Redonda.

Oswaldo Carminatti ingressara no PCB entre final de 1957 e início de 1958, ao comparecer a uma reunião do partido na Avenida Joaquim Leite, em Barra Mansa, onde

\footnotetext{
${ }^{59}$ Superintendência Da Política Agrária. Foi um órgão criado em 11 de outubro de 1962, que tinha entre suas finalidades colaborar na formulação da política agrária do país; planejar, executar e fazer executar, nos termos da legislação específica, a reforma agrária; promover a desapropriação de terras por interesse social, objetivando a justa distribuição da propriedade rural, condicionando seu uso ao bemestar social, e prestar serviços de extensão rural e de assistência técnica aos trabalhadores rurais. Cf. Superintendência da Política Agrária. (Verbete). Disponível em: http://www.fgv.br/cpdoc/acervo/dicionarios/verbete-tematico/superintendencia-da-politica-agrariasupra. Acesso em: 20 jun. 2017.

60 Antônio da Rocha Machado procurara acalmar os companheiros recolhidos na prisão do 10 BIB e representava os prisioneiros junto ao Oficial do Dia. Interrogatório de Anaxágoras Rattes, datado de 7 de maio de 1964. Autos do IPM- PCB 7.478/64, p. 93 e ss.

${ }^{61}$ Interrogatório de Pedro Silva, datado de 5 de maio de 1964. Autos do IPM- PCB 7.478/64, p. 74 e ss.

62 Interrogatório de Juracy Vieira de Souza, datado de 3 de maio de 1964. Autos do IPM- PCB 7.478/64, p. 57 e ss.
} 
funcionava a sede do PSD, a convite de Maurício Grabois. Por essa época era candidato a vereador pelo PSD que, segundo Carminatti, sabia de sua filiação com o partido comunista. ${ }^{63}$

Carminatti, Juracy e Argollo teriam sido os responsáveis pela reorganização do partido na cidade de Barra Mansa, pelo aumento dos seus membros e pela organização do comitê municipal, este com a participação dos três e também de José Maria Cordeiro, Ceciliano, Dorvano Fabiano, Paulo Alves Ferreira, José Delgado Cortez, Cândido de Souza (sic - seria da Silva?). À época foram eleitos para o secretariado 3 membros da diretoria: Juracy, Dorvano e Argollo, que também compunham a comissão de finanças. Havia ainda a Base do Centro, que era composta por Carminatti, Dorvano e Argollo, a Base de Saudade, composta por outros 3 membros, entre eles o Candido de Souza (Pernambuco), e a Base Júlio Cajazeiras, cujos integrantes Carminatti teria dito não conhecer. Eram Assistentes Estaduais do PCB, Grabois, ${ }^{64}$ Sabença, Feliciano e José Milan. As reuniões do partido eram realizadas na rua Mário Ramos, no 58 , sala 105 , na sede do diretório do PST. ${ }^{65}$

Várias pessoas contribuíam financeiramente para o partido em Barra Mansa. Entre elas estava Elias Bondarovsky, um ucraniano que havia entrado no Brasil ilegalmente, mas que declarava ter vindo para o país aos 2 anos de idade (sem provas disso, em 1930, pagou 100 mil réis para o cartório de Barra Mansa registrá-lo como nascido na cidade no ano de 1912). Era industrial e comerciante, possuidor de uma fortuna sólida, tinha, inclusive, uma loja de móveis na cidade, contribuía com alto valor para o PCB de Barra Mansa, desde 1951. Os valores por ele doados variavam entre 500 e 1 mil cruzeiros.

Já Alcides Rodrigues Sabença era o líder comunista em Barra do Piraí. Ingressara no Partido Comunista no ano de 1943, em Volta Redonda, passando a fazer parte do Comitê Distrital no partido nesta cidade. Em dezembro de 1945 foi eleito deputado pelo PCB. Como o registro do partido foi cassado em maio de 1947, voltou a assumir suas funções na CSN em setembro daquele ano, mas, logo no mês seguinte, foi desligado da empresa. Passou a trabalhar como carpinteiro em Barra do Piraí, onde retomou suas atividades partidárias. Assumiu a função de Assistente Estadual do Partido, junto ao Comitê Municipal de Barra Mansa.

Sabença era adepto da linha russa, que preconizava soluções pacíficas para os problemas, o que o distanciava de Anaximandro Rattes, seguidor da linha chinesa, que preconizava a violência, e de Waldemar Argollo. Para ele, os comunistas se dividiam em adeptos da linha russa ou chinesa, o que provocava divisão no partido. Fazia contribuições

\footnotetext{
${ }^{63}$ Segundo Edgard Bedê, os comunistas também se abrigavam na legenda do PSD no estado do Rio de Janeiro. Havia na Câmara Municipal de Barra Mansa, em 1949, um vereador do PSD que era comunista, o Sr. Henrique Manoel Ferreira. Em Volta Redonda, os comunistas, através do Comitê Municipal, aparelharam o PSD e elegeram dois vereadores, Silveira Pereira Rosa e Feliciano Neto. Cf. BEDÊ, Edgard. A Formação da Classe... Op. cit., p. 79; 102; 182.

${ }^{64}$ Maurício Grabois havia se filiado ao PC do B em 1962, o que sugere uma confusão entre os partidos comunistas na região e que, portanto, poderiam atuar de forma mais unificada na prática.

${ }^{65}$ As reuniões ocorridas na sede do PST eram semanais e tinham a função de tratar das reivindicações do povo residente nos bairros e as atividades dos comunistas. Cf. Interrogatório de Oswaldo Carminatti, em interrogatório datado de 4 de maio de 1964. Autos do IPM- PCB 7.478/64, p. 66 e ss.
} 
mensais para o partido, chegando a $\mathrm{Cr} \$ 1500,00{ }^{66}$ Era membro do Comitê Central do PCB em Barra do Piraí, sob a orientação de Alexandre José de Lima, do qual ainda faziam parte Almair Mendes de Avelar, Júlio Barbosa da Silva, Joaquim Gonçalves Dias, José da Silva. Como Alexandre Lima fora expulso do partido, Sabença assumiu a direção do comitê. As reuniões do comitê, que mantinha contatos permanentes com a CGT, ocorriam aos domingos pela manhã. Lindolfo Hil era assistente estadual do PCB e transmitia as orientações da cúpula do partido para o comitê. Júlio Barbosa, adepto da linha chinesa, também foi expulso do partido. Barbosa organizou o Sindicato Rural em Ipiabas e tinha ligação com as Ligas Camponesas. José da Silva e Joaquim Gonçalves Dias eram do setor ferroviário do partido. Segundo Sabença, a orientação era para apoiar as Reformas de Base do governo Jango.

$O$ inquérito policial militar foi transformado em processo e julgado pelo Conselho Permanente de Justiça da $2^{a}$ Auditoria Militar em 26 de junho de 1970. Em decisão unânime, julgou pela absolvição de quase todos os réus citados no IPM. Apenas foram condenados Leonel de Moura Brizola, Luiz Carlos Prestes, Maurício Grabois e Lincoln Cordeiro Oest, que deveriam cumprir 10 anos de prisão. Entretanto, a extinção da punibilidade pela prescrição da pena foi decretada em maio de 1979.

\section{Conclusão}

Com o golpe civil-militar de 1964 e a influência do trabalhismo e do comunismo sobre os trabalhadores da região, o $1^{\circ}$ BIB passou a ser o principal órgão de repressão aos opositores do novo regime. Logo após o golpe, esses opositores, entre eles os comunistas, foram perseguidos, presos e interrogados pelas autoridades militares do batalhão. Um Inquérito Policial Militar (IPM) foi instaurado para averiguação das atividades dos comunistas na região, a partir do qual podemos verificar como agiam seus integrantes.

A presença de políticos de projeção nacional como Luís Carlos Prestes, Leonel Brizola, Maurício Grabois e Wladimir Pomar, nas atividades dos comunistas na região assinalada, demonstra a importância que a mesma tinha como base de apoio político dos grupos à esquerda do espectro político, como os trabalhistas e os comunistas, devido à grande concentração local de operários e trabalhadores no geral.

A tentativa de greve na CSN, por parte do Sindicato dos Metalúrgicos dirigido pelos comunistas, com o objetivo de resistir ao golpe acabou malograda. O serviço de segurança da CSN prendeu todas as lideranças sindicais no prazo de uma semana, sendo levados para o $1^{\circ}$ BIB, em Barra Mansa, ou para a AMAN, em Resende. Havia um Plano de Segurança da Usina, concebido pelo Comando Militar, sob a liderança do tenente-coronel Luciano Salgado Gomes,

\footnotetext{
${ }^{66}$ Interrogatório de Alcides Rodrigues Sabença, datado de 9 de junho de 1964. Autos do IPM- PCB $7.478 / 64$, p. 244 e ss.
} 
aliado ao Diretor Industrial, ${ }^{67}$ que tinha o controle das superintendências dos departamentos da empresa. As ações dos sindicalistas demonstraram falta de planejamento, com decisões espontâneas tomadas no calor da hora, com tentativas frustradas de paralisação da Usina. ${ }^{68} \mathrm{~A}$ CSN havia desenvolvido, pela sua Superintendência de Assistência Social, uma estrutura de controle e dependência do empregado, sua família e sua vida social, aos serviços de moradia, transporte, abastecimento de água, iluminação, rede de esgoto, limpeza, segurança, abastecimento alimentar, educação, saúde, lazer e cultura, sob a responsabilidade social da companhia, difundindo, juntamente, o ideário de colaboração entre capital e trabalho. ${ }^{69} \mathrm{~A}$ rápida repressão militar e prisão das lideranças e ainda o temor de perder o emprego na CSN podem ter diminuído o ímpeto de resistência ao golpe pelos metalúrgicos.

Pela rápida identificação e prisão das lideranças comunistas e demais membros, como se pode verificar pelo IPM, podemos concluir que as atividades do PCB e do PC do B, mesmo na ilegalidade, não eram secretas, e sim bastante conhecidas na região. Tinham notada atuação durante o governo Jango, principalmente no movimento sindical e operário, sem maiores restrições. Sabia-se, inclusive, que outros partidos, como o PST, o PTB e o PSD, davam cobertura aos seus integrantes.

Os comunistas na região seguiam a cisão nacional, vendo-se rachados em 2 correntes: a chinesa, que propunha ações revolucionárias violentas, e a russa, que propunha o caminho democrático, o que pode ter trazido o enfraquecimento da ação comunista devido às discordâncias operacionais. Seus integrantes tentaram organizar na região os Grupos de Onze, arquitetados por Leonel Brizola, mas, ao que parece, sem muito êxito, talvez pelo golpe não Ihes ter dado suficiente tempo. Tentaram também organizar as Ligas Camponesas, o que foi frustrado pela repressão do 10 BIB.

Entretanto, o célere desbaratamento dos grupos comunistas que foram identificados e presos no $1^{\circ}$ BIB ainda em abril de 1964, demonstra sua frágil organização e consistência. 0 total de integrantes presos, entre lideranças e colaboradores, também sugere que os comunistas não teriam tanta entrada entre as classes populares. Observa-se, ainda, que a influência dos militares através da presença do 10 BIB na vida cotidiana dos habitantes das cidades acima identificadas e suas atividades repressivas desde a década de 1950 podem ter contribuído para uma maior resistência à disseminação da ideologia comunista pela população local.

Para Otávio Ianni, ${ }^{70}$ a explicação para o golpe civil-militar estaria principalmente nas contradições da esquerda brasileira, que se dividia entre as propostas revolucionárias do marxismo-leninismo e a prática populista, que Ihe abria espaço de apoio entre as massas

\footnotetext{
${ }^{67}$ A direção da CSN era formada em 1964 por dois grupos distintos: um vinculado ao governo Jango, como o presidente da CSN, o almirante Lucio Meira, entre outros, e o vinculado ao Capital, como o Diretor Industrial, o engenheiro Mauro Mariano da Silva, entre outros. Cf. BEDÊ, Edgard. A Formação da Classe... Op. cit., p. 235.

${ }^{68}$ Para Santana, com o golpe dado, os sindicatos foram pegos de surpresa e estavam pouco preparados para reagir. Cf.: SANTANA, Marco Aurélio. Ditadura Militar e... Op. cit., p. 134.

${ }^{69}$ BEDÊ, Edgard. A Formação da Classe... Op. cit., p. 101; 252; 259; 277; 279.

${ }^{70}$ IANNI, Otávio. O Colapso do Populismo no Brasil. Rio de Janeiro: Civilização Brasileira, 1975, p. 100.
} 
trabalhadoras. Para Jacob Gorender ${ }^{71}$ o PCB não compreendeu a força da burguesia brasileira e apostava que seria possível hegemonizá-la, trazendo-a a reboque de seu projeto revolucionário. Além disso, confiara demais na capacidade política de Jango em levar à frente as reformas sociais e debelar o golpe, o que chamara de "reboquismo" do partido.

René Dreyfuss encontra explicação na própria crise do populismo, em que este era transformado em meio à luta de classes, passando da manipulação para a participação política das classes trabalhadoras. ${ }^{72} \mathrm{O}$ progressivo alinhamento de Jango às demandas das classes populares teria feito com que as frações das classes dominantes, tais como a oligarquia rural e a burguesia financeiro-industrial, se movessem em busca de uma reconciliação política, o que o autor chama de "bloco multinacional e associado". As Forças Armadas, por sua vez, agiram quando viram sua hierarquia em perigo, devido às sublevações do suboficialato, e o declínio de seu padrão de vida material. Esses grupos se articularam em um bloco civil-militar de tendências cesaristas, legitimadas pela doutrina de segurança nacional disseminada pela Escola Superior de Guerra (ESG). ${ }^{73}$

Marco Aurélio Santana busca explicações do fracasso na resistência ao golpe em alguns fatores. ${ }^{74}$ Entre eles estavam a imediata prisão das lideranças sindicais, que cortara a cabeça de um movimento dos trabalhadores que primava pelo "cupulismo" de suas lideranças e a falta de trabalho consistente na base operária. Entre os motivos desse cupulismo estaria a extração dos militantes de base para os organismos sindicais superiores, provocando um "fosso" de contato entre lideranças e a base. O resultado do descompasso entre lideranças e o operariado de base teria sido uma tentativa de greve, que se revelou desarticulada, com a paralisação de setores esparsos. Não se formularam outras formas de ação que não a greve.

Outro fator do fracasso seria o reboquismo dos comunistas em relação ao governo Jango, já assinalado por Gorender, o que não teria passado de uma ilusão transitória devido a uma confiança exagerada na capacidade do governo em debelar o golpe. Além desses, o autor cita o fato de que parte da direção do CGT era contrária à greve geral de resistência ao golpe, pois acreditava que prejudicaria a movimentação dos trabalhadores e as orientações de Jango para não se resistir ao golpe e evitar o derramamento de sangue. Os arranjos políticos, por um lado, e o controle sobre o movimento de massa dos trabalhadores, por outro, falharam na resistência ao golpe devido a sua desconexão e desarticulação.

\footnotetext{
${ }^{71}$ GORENDER, Jacob. Combate nas Trevas. Op. cit., p. 62.

72 DREIFUSS, René Armand. 1964... Op. cit., p. 141-142.

${ }^{73}$ Entidade criada em 22 de outubro de 1948 pelo Decreto n. 25.705 e organizada de acordo com a Lei n. 0 785, de 20 de agosto de 1949 e subordinada à Presidência da República através do Estado-Maior das Forças Armadas (EMFA). Entre os propósitos que presidiram sua fundação estava o de se tornar uma agência socializadora das elites brasileiras, militares e civis em torno de questões referentes à segurança e desenvolvimento do país, numa espécie de foro acadêmico. Cf.: Escola Superior de Guerra (ESG). (Verbete). Disponível em: http://www.fgv.br/cpdoc/acervo/dicionarios/verbete-tematico/escola-superiorde-guerra-esg. Acesso em: 20 jun. 2017.

${ }^{74}$ SANTANA, Marco Aurélio. Ditadura Militar e... Op. cit., p. 135-138.
} 